\title{
Starving Millions and Right to Food
}

\author{
Sai Teja Vangala* and Anshuman Singh**
}

\begin{abstract}
Right to food is a basic human right. In India, with increase in population the demand for food is on the rise. Providing adequate food to the teeming millions has been a challenge for the government. This paper explores the origin of right to food while placing the emphasis on the realisation of the right in its true sense. It argues that the state has failed to secure adequate food to its citizenry because of its misplaced priorities and lack of political will. It calls for strengthening of public distribution system and buffer stock to guarantee adequate food security to people.
\end{abstract}

Keywords: Food Security, Hunger, Legislation, Poverty, Right to Food

\section{Introduction}

Food is one of the basic necessities of human life and existence. Every human being has a right to be free from hunger and to have access to safe and nutritious food. Right to food is a human right. This right is about ensuring that all people have the capacity to feed themselves in dignity. ${ }^{1}$ However the problems of hunger,

\footnotetext{
* Fifth Year, BA LLB (Hons.), National Law University, Delhi.

** Fifth Year, BA LLB (Hons.), National Law University, Delhi.

1 Jean Ziegler, What is the Right to Food?, (Jan. 3, 2011),

http://www.righttofood.org/new/html/WhatRighttofood.html (last visited Apr. 23, 2012).
} 
malnutrition and starvation deaths are rampant in various parts of the world. Every seven seconds, a child under the age of 10 dies from hunger or hunger-related diseases. ${ }^{2}$ Nearly $50 \%$ of the world's hungry people live in India, a low-income, food-deficit country. Around 350 million people in India, constituting about $35 \%$ of the population of the country are considered food-insecure. These people consume less than $80 \%$ of minimum energy requirements. Nutritional and health indicators are extremely low. ${ }^{3}$

The "Right to Food" was first mentioned in the 'Economic Bills of Rights' by US President Franklin D. Roosevelt in 1944. ${ }^{4}$ This was three years after he made his memorable "Four Freedoms Speech." 5 The first Millennium Development Goal (MDG) of the United Nations also focuses on eradication of 'extreme poverty and hunger'. ${ }^{6}$ It was observed that 'achieving this goal is fundamental to the overall attainment of the Millennium Development Goals. Poverty and Hunger are both the causes and consequences of lack of education, gender discrimination, ill health and the overexploitation of fragile ecosystems' ${ }^{\prime}$

2 U.N. Special Rapporteur on the Right to Food, Economic and Social Council, Jan. 10, 2003, U.N. Doc. E/CN.4/2003/54.

3 World Food Programme, Overview (Jan. 3, 2011), http:// www.wfp.org/ countries/India/Overview.

${ }^{4}$ Hans Morten Haugen, The Right To FoOd AND The Trips AgreEment: With A Particular EMPHASIS On DeVeloping Countries' MEAsure For FoOd PRODUCTION AND Distribution 14 (Martin Nijhoff Publishers, $1^{\text {st }}$ ed. 2000); see also Food and Agricultural Organization, Achieving the Right to Food - The Human Rights challenge of the Twenty-First Century (Jan. 8, 2011), http:// www.fao.org/ righttofood/ wfd/pdf2007/ wfd_leaflet_en.pdf.

5 Franklin D Roosevelt, Four Freedoms (Jan. 6, 1941), http://www.archives.gov/exhibits/powers_of_persuasion/four_freedo $\mathrm{ms} /$ four_freedoms.html. (including the Four Freedoms: Freedom of Speech and Expression, Freedom of Religion, Freedom from Want, Freedom from Fear); see also HAUGEN, supra note 4.

${ }^{6}$ Millennium Development Goals, United Nations Development Programme (Jan. 20, 2011), http://www.undp.org/mdg/goa1.html.

7Id. 
In the period 1990-2015, Asia and the Pacific regions are expected to have the proportion of people living below the internationally recognised poverty line (i.e. a dollar a day). However, despite having the fastest economic growth rates in the world, these regions continue to harbour the poorest people in the world. "The latest estimates show that more than 700 million people still live on less than $1 \$$ a day in this region, accounting for more than twothirds of the world's extreme poor." 8

In India, more than 200 million people are food insecure. Out of those families that face the problem of hunger about half are households that have at least one working member, ${ }^{9}$ and all this at a time when the Food Corporation of India's buffer stocks hold grains three times their capacity. ${ }^{10}$

\section{Status of Right to Food in International Jurisprudence: A Fundamental Human Right?}

The right to food is deeply rooted in international human rights law such as the Universal Declaration of Human Rights, 11 the International Covenant on Economic, Social and Cultural Rights. ${ }^{12}$ It also flows from the Declaration of the Rights of the Child, 13 the

${ }^{8} \mathrm{Id}$

${ }^{9}$ Government of India, Implementation of the International Covenant on Economic, Social and Cultural Rights: Periodic Report Submitted to by States parties under articles 16 and 17 of the Covenant, Combined Second, Third, Fourth and Fifth Periodic Report of India, U.N. Doc. E/C.12/IND/5 (Mar. 1, 2007).

10 B.B Pande, Reorienting the 'Rights' Discourse to Basic Human NeEdS, in Human Rights and Basic NeEds: THeORy AND Practice 149 (M.P Singh, et al. eds., 2008).

${ }^{11}$ Universal Declaration of Human Rights, U.N. Doc. A/810, U.N GAOR $3^{\text {rd }}$ Session, $1^{\text {st }}$ Plenary Meeting, art. 25.

12 International Covenant on Economic, Social and Cultural Rights, U.N Doc. A/ 6316 (1966), 993 U.N.T.S. 3, art. 11.

${ }_{13}$ Declaration of the Rights of the Child, Principle 4, U.N Doc. A/4354 (1954), 14 U.N GAOR Supp. (No. 16) at 19. 
Declaration on the Protection of Women and Children in Emergency and Armed Conflict, 14 the Geneva Conventions, the Universal Declaration on the Eradication of Hunger and Malnutrition. ${ }^{15}$ The importance of right to food was also emphasised in General Comment No. 12 of the Committee of International Covenant on Economic, Social and Cultural Rights in 1999. It laid down that "the right to adequate food is indivisibly linked to the inherent dignity of the human person and is indispensable for the fulfilment of other human rights enshrined in the International Bill of Human Rights. 16 The right is also inseparable from social justice, requiring the adoption of appropriate economic, environmental and social policies, at both national and international levels, oriented to the eradication of poverty and the fulfilment of all human rights for all." 17

Article 11 of the International Convention on Economic, Social and Cultural Rights enshrines the right to food in the following words:

"1. The State Parties to the present Covenant recognise the right of everyone to an adequate standard of living for himself and his family, including adequate food, clothing and housing, and to the continuous improvement of living conditions.

2. The State Parties to the present Covenant recognising the fundamental right of everyone to be free from hunger, shall take individually and through international co-operation, the measures, including specific programs, which are needed:

\footnotetext{
14 Declaration on the Protection of Women and Children in Emergency and Armed Conflict, U.N Doc. A/RES/29/3318, 29 U.N GAOR Supp. (No. 31), art. 6.

15 Universal Declaration on the Eradication of Hunger and Malnutrition, U.N Doc. E/CONF. 65/20 (1974) 1, [UDEHM], art. 1.

16 International Covenant on Economic, Social and Cultural Rights Preamble, U.N Doc. A/6316 (1966), 993 U.N.T.S. 3; International Covenant of Civil and Political Rights, U.N Doc. A/6316 (1966), 999 U.N.T.S 171.

17 General Comment No. 12 of the Committee on Economic, Social and Cultural Rights the Right to Food, UN doc. E/2000/22; see also F.A.O., supra note 4.
} 
a. to improve the methods of production, conservation and distribution of food by making full use of technical and scientific knowledge, by disseminating knowledge of the principles of nutrition and by developing or reforming agrarian systems in such a way as to achieve the most efficient development and utilization of natural resources;

b. to ensure an equitable distribution of world food supplies in relation to need." 18

Article 11.2 of ICESCR however forms the core of the right to food as it enshrines the "right to be free from hunger." 19

The office of the UN High Commissioner for Human Rights pressed for further clarification of the Right to Food and in 1999 the United Nations Committee on Economic, Social and Cultural Rights adopted a 'legally authoritative' understanding of the right to food in terms of availability (including adequacy as well as acceptability) and accessibility. ${ }^{20}$ In a similar way, the International Food and Agricultural Organisation also recognizes the right to food as operational food security, when all people, at all times, have physical and economic access to sufficient, safe and nutritious food to meet their dietary needs and food preferences for an active and healthy life." 21

The international legal context thus provides a basic framework for a preliminary conjectural analysis. At the core of the right to food, as an operational as well as a normative concept, availability and accessibility stand out as two key elements. ${ }^{22}$ Food has to be available either directly from productive land or other natural resources. Availability can also be guaranteed through an effective processing and distribution system which ensures the transportation of foodstuffs from production sites to those areas

18 M.P SinGH, HuMAN RigHTS AND BASIC NEEDS: THEORY AND PRACTICE 195 (2008).

${ }^{19}$ General Comment No. 12 of I.C.E.S.C.R., supra note 17.

${ }^{20}$ HAUGEN, supra note 4.

21 SINGH, supra note 18 at 196.

22 Id. 
where food is in demand. At the same time, our legal frame of reference clearly goes beyond the mere physical availability of food, as the adequacy and acceptability of foodstuffs form an important part of the right to food. Hence, food not only has to satisfy dietary needs (energy and nutrients) but it should be culturally acceptable and safe, i.e. without contaminants or noxious elements. ${ }^{23}$

Finally, the accessibility of food has to be measured with respect to economic and physical hurdles that have to be overcome for its acquisition; the right to food discourse thus implies that financial costs for food should not destabilise other basic needs.

\section{The Role of Nation-States in Securing Adequate Food to its Citizenry}

The Convention relating to Human Rights are generally formulated with the individual as endowed with the right to food. The Convention also cast a duty on the state to ensure the realisation of this right to the people. When a nation-state ratifies such an international instrument, it takes upon itself specific duties towards its inhabitants. Since the state is under a duty to procure food to its citizens, it is essential that it should adopt a proactive stance on the same. For the fulfilment of the right to food, the state shall restrict itself to a provider. It is equally important that it creates an 'enabling environment for the farmer' ${ }^{24}$ This directs one's attention to the question of the state providing access to relevant information on new seeds or new food to the farmer, and also contributing to such improvements with a view to make them widely accessible. "The right to adequate food, like any other human right, imposes three types or levels of obligations on states parties: the obligations to respect, to protect and to fulfil." 25

\section{${ }^{23} \mathrm{Id}$. \\ ${ }^{24} I d$.}

${ }^{25}$ General Comment No. 12 of ICESCR, supra note 17; SINGH, supra note 18. 
The states also have 'obligations of conduct and of result' 26 - the obligations of conduct cast a duty on the state to take reasonably calculated proactive measures to realise the enjoyment of a particular right, while the latter emphasises the states' obligation to achieve results in terms of substantive targets. The nation-states are thus obligated to ensure that their people are not deprived of their right of access to food or food producing resources, as the case may be. Therefore, the nation-states are prohibited to enact any legislation or pass any administrative order that would:

1. Destroy people's right of access to food or food producing resources.

2. Prevent people from maintaining access to food or food producing resources. ${ }^{27}$

This obligation of the states essentially translates as their duty to 'actively prevent third parties' from depriving people of either their access to food or food producing resources. ${ }^{28}$ The first two obligations pertain to the access to food. If the destructive agent is the States' authority this act is undoubtedly violation of the human right to food. However, if the destructive agent is a third party, this act becomes a crime against the human right to food. 29

The third type of obligation deals with persons or groups who lack access to food or food producing resources (instead of protecting those who already possess it). This is an obligation and requires the state to provide both access and resources to those who do not already possess them. The resources here will include

${ }^{26}$ Urban Morgan Institute for Human Rights, International Commission of Jurists, The Maastricht Guidelines on Violations of Economic, Social and Cultural Rights, Human Rights Quarterly 20.3 (1998) 691-704.

27 SINGH, supra note 18 at 177.

${ }^{28} \mathrm{Id}$.

${ }^{29} \mathrm{Id}$. 
employment, ${ }^{30}$ and the sharing of resources and food in systems of social security (based on the state, community and family). ${ }^{31}$

Since human rights give rise to state obligations, their violation are considered as a breach of these obligations. This is true for the right to food just as it is for any other human right. For the states parties to the ICESCR these are legal obligations under international law. This is formulated as follows:

"Each state party to the present Covenant undertakes to take measures, individually and through international assistance and co-operation, especially economic and technical, to the maximum of its available resources, with a view to achieving progressively the full realisation of the rights recognised in the present Covenant by all appropriate means, including particularly the adoption of legislative measures." 32 The key terms here are "progressive achievement' and 'maximum available resources'.

States however, have to use the maximum available resources to protect and fulfil the right to food. Priorities must be given to the 'core content' and hence to the most vulnerable individuals. ${ }^{33}$ It is interesting to note that a violation of the Covenant occurs when these 'core obligations' are not fulfilled which apply irrespective of the availability of resources (or any other such particularities) of the country concerned. ${ }^{34}$

More generally, under the provision of maximum available resources, states are expected to use all means in their power and to do their best to meet their obligations under the right to food. "This imposes an obligation to move as expeditiously as possible towards this goal." 35 Taking the steps progressively is only permissible due

30 See generally Mahatma Gandhi National Rural Employment Guarantee Act, 2005.

${ }^{31} I d$.

32 International Covenant on Economic, Social and Cultural Rights Preamble, supra note 16 art. 2.1; see also SINGH supra note 18 at 178.

33 SINGH, supra note 18 at 177.

${ }^{34}$ General Comment no. 12 of ICESCR, supra note 17.

${ }^{35} \mathrm{Id}$. 
to lack of resources and in such cases, states have the burden of proving that they lack the resources. ${ }^{36}$ However, this provision must be understood in consonance with the concept of 'core obligations' discussed above. The state parties have "a minimum core obligation to ensure the satisfaction of, at the very least, minimum essential levels of each of the rights. Thus, for example, a state party in which any significant number of individuals is deprived of essential foodstuffs, health care, of basic shelter and housing, or of the most basic forms of education, is prima facie, violating the covenant." 37 The state claiming inability to carry out its obligation for reasons beyond its control has to prove that it has unsuccessfully sought to obtain international support to ensure the availability and accessibility of the necessary food.

\section{Access to Adequate Food}

Due to the changing perspective of the role of nation-states ratifying international human rights instruments, there has been a shift of emphasis from mere availability of food (i.e. increased production) to addressing access to food. ${ }^{38}$ While the major concern relating to food (especially in developed economies) is food quality, this is less of a concern in developing countries. ${ }^{39}$ General Comment 12 recognises both adequacy of food and access to food, and observes that the "accessibility encompasses both physical and economic accessibility." 40 This could be understood that if a person or community has access to food as a result of its economic activities (used in the widest possible sense to include direct food production based on resources such as natural means-like land, water, forests, pastures, fishing grounds; capital resources liketools, funds, technologies; and human resources, i.e. skills and knowledge) then food is said to be economically accessible. ${ }^{41}$

${ }^{36} I d$.

${ }^{37} \mathrm{Id}$.

38 HAUGEN, supra note 4 at 18.

${ }^{39} \mathrm{Id}$.

${ }^{40}$ General Comment No. 12 of ICESCR, supra note 17 at $₫ 13$.

${ }^{41}$ SINGH, supra note 18 , at 175 . 
Therefore, the normative content containing both economic and physical access to food implies the entitlement to access the means of its procurement: natural and other resources- skills, knowledge, market, funds etc. 42

Physical accessibility to food however, does not take into account whether or not the food is accessed in return for an economic activity. It only focuses on immediate physical access. ${ }^{43}$ This implies that physical accessibility ensures that those who are not able to or are not willing to make use of the economic resources at their disposal should still have access to food. General Comment observes that the "physical accessibility implies that adequate food must be available to everyone." 44

Therefore, it maybe surmised that physical accessibility of food is unconditional, just as the right to an adequate standard of living is unconditional, i.e. access to food is in particular free from conditional requirements such as economic activities or specific merits. It is independent of the question of whether the person in question 'deserves aid' or not. ${ }^{45}$

Apart from economic and physical accessibility there are other requirements - such as that the food should be made accessible in a way which is sustainable. This may be seen as a partly ecological and partly economic requirement. ${ }^{4}$ "The notion of sustainability is intrinsically linked to the notion of adequate food or food security, implying food being accessible for both present and future generations and sustainability incorporates the notion of long term availability and accessibility." 47 This means that the accessibility of food must not be fluctuating and sporadic but steady over a long period of time (long-term accessibility) and that there are certain

42 Id. at 176.

${ }^{43} I d$.

${ }^{44}$ General Comment No. 12 of ICESCR, supra note 17 at $\ 13$.

45 International Covenant on Economic, Social and Cultural Rights Preamble, supra note 16 art. 11.

${ }^{46}$ General Comment No. 12 of ICESCR, supra note 17 at 98.

$47 \mathrm{Id}$. at 7. 
ecological limits to food production and distribution (long-term availability).

Another consideration in ensuring adequate access to food as a basic human right is that it should be implemented in a way which is sensitive to one's dignity as a human being. ${ }^{48}$ This warning about non-interference with the enjoyment of other human rights reminds us that the right to food is an integral part of human rights, and in particular of the human right to an adequate standard of living.

\section{Status of Right to Food in India}

Human rights and basic needs for most people in poor countries are less a matter of theory than of practice. This especially applies to food in India where food security is less a question of harvests and quantities than of entitlement and deprivation which has been proved already. ${ }^{49}$ Sen's analysis of the Bengal famine of 1943 and other twentieth century famines shows that "starvation is the characteristic of some people not having enough to eat. It is not the characteristic of there being not enough food to eat." 50

In India, one or two famines occurred almost every decade in the nineteenth century. ${ }^{51}$ Today the country feeds its population in a better manner than in the past despite the fact the population has more than tripled since independence. ${ }^{52}$ But this is only an average - there are still more people undernourished in India than any other region of the world despite the fact that the Government of

${ }^{48}$ U.N. Economic and Social Council, Special Rapporteur on the Right to Adequate Food as a Human Right, (Jul. 9, 1987) ECOSOC E/CN. 4/Sub. 2/1987/23.

${ }^{49}$ Amartya Sen, Poverty and Famines: An essay on entitlement and deprivation in SINGH, supra note 18 at 191.

${ }^{50} \mathrm{Id}$.

51 ROMESH DutT, FAMINES AND LAND ASSESSMENTS IN INDIA 1 (BR Publications, 1985).

$52 I d$. 
India is sitting on unprecedented amounts of food grains in its reserves.

As India is a member of the Food and Agricultural Organization, it is noteworthy that the Constitution of FAO in its Preamble provides that "the Nations accepting this Constitution, being determined to promote the common welfare by furthering separate and collective action on their part for the purpose of raising levels of nutrition and standards of living ... and thus ... ensuring humanity's freedom from hunger...." 53 Alongside these instruments, numerous conferences and non-binding international declarations and resolutions have shaped the emerging international consensus on norms regarding the right to food. ${ }^{54}$

The right to food is linked to several, if not all, other human rights, namely right to life, right to health, right to livelihood, freedom of association, expression and information, right to private property, and right to education. ${ }^{55}$ Article 47 of the Constitution states that: "The State shall regard the raising of the level of nutrition and the standard of living of its people and the improvement of public health as among its primary duty." Although the right to food is not directly justiciable, its inclusion in the Directive Principles of State Policy serves to guide interpretation of fundamental rights, including the right to life protected by Article 21 of the Constitution. The Supreme Court has held that "the right to life guaranteed in any civilised society implies the right to food, water, decent environment, education, medical care and shelter." 56 The

53 Food and Agricultural Organization, Constitution of the FAO of the United Nations,

www.fao.org/DOCREP/003/X8700E/x8700e01.htm\#P8_10 (last visited Mar. 13, 2011).

54 Pooja Ahluwalia, The Implementation Of The Right To Food At The National Level: A Critical Examination Of The Indian Campaign On The Right To Food As An Effective Operationalization Of Article 11 Of ICESCR, http:/ / www.chrgj.org/publications/docs/wp/Ahluwalia\%20Implement ation $\% 20$ of $\% 20$ the $\% 20$ Right $\% 20$ to\%20Food.pdf (last visited Mar. 18, 2011).

${ }^{55} \mathrm{Id}$.

56 Chameli Singh \& Others v. State of Uttar Pradesh, (1996) 2 S.C.C. 549. 
State has a constitutional obligation to take steps to ensure a dignified life to all individuals. The citizen's right to be free from hunger enshrined in Article 21 is to be ensured by the fulfillment of the obligations of the State set out in Article 47 of the Constitution.

\section{Poverty and Food Security}

Hunger is a huge problem in India. One does not have to look far and wide for numerous instances of mass starvation deaths: some recent cases include the Kalahandi region in Orissa; in Sahariya, a village in the Baran district of Rajasthan where the tribes could not practice their traditional livelihood of gathering forest wood to sell in the nearby town due to continuous rain in August 2004. Therefore there was no employment and the people had no money to buy food. Then in August 2005, a six-member team led by the State Advisor to the Commission of the Supreme Court, visited these areas and confirmed cases of chronic hunger. ${ }^{57}$ Such cases are reported by a sensitive and watchful media. Improving food security therefore becomes an issue of immense importance. There are various ways in which food security may be defined and accordingly there are various methods for its improvement. ${ }^{8}$ The various government strategies here include among others economic growth, direct anti-poverty programmes which include selfemployment programmes, public distribution systems, nutrition based programmes and provision for health facilities. ${ }^{59}$

A comprehensive study on the two most important methods to implement food security was carried out in 1996. A comparison of the efficacy of the two systems of PDS (Public Distribution System) and the EGS (Employment Generation Scheme) then prevalent in states of West Bengal and Maharashtra was made and it was laid down that "a mix of policies is needed to improve the food

57 George Cheriyan, Enforcing the Right to Food in India: Bottlenecks in Delivering the Expected Outcome, UNU-WIDER RESEARCH PAPER NO. 2006/132, 1-2 (2006).

58 S. Mahendra Dev, Food Security: PDS vs. EGS - A Tale of Two States, ECONOMIC AND POLITICAL WEEKLY VOL. 31, No. 27, 1752-1764 (Jul. 6, 1996). ${ }^{59} \mathrm{Id}$. 
security. An effective PDS along with other anti-poverty programmes can reduce poverty in the country. The PDS has to be more targeted to agricultural labourers in the rural areas for both Maharashtra and West Bengal." 60 Controlling inflation, improving health facilities is also needed for increasing food security in the two states of Maharashtra and West Bengal and in other parts of the country. ${ }^{61}$

The central food schemes and other assistance programmes for the poor in India are Public Distribution System, Antyodaya Anna Yojana, Mid Day Meal Scheme, Annapoorna Yojana; Integrated Child Development Services, National Family Benefits Scheme, National Maternity Benefit Scheme, and National Old Age Pension Scheme. ${ }^{62}$ But perhaps the pioneering legislation in this regard has been the enactment of the Mahatama Gandhi National Rural Employment Guarantee Act, 2005. The realisation of the human right to food is inextricably linked with that of the fundamental right to work. The right to work gives the unemployed the resources to obtain access to adequate food and therefore satisfy the economic access to food as demanded by the ICESCR.

\section{Domestic Jurisprudence Relating to Right to Food}

Through myriad judgments the apex court has continuously enlarged the scope of the fundamental right to life guaranteed under Article 21 of the Constitution. Whether it be the Olga Tellis case stating that 'the right to life includes right to live with at least the basic means of subsistence,' 63 or the case of Keshavananda Bharti where the Supreme Court opined that 'freedom from starvation is as important as the right to life.' ${ }^{64}$ Judgments like these have

${ }^{60} \mathrm{Id}$.

${ }^{61} \mathrm{Id}$.

62 HAUGEN, supra note 4 at 6.

63 Olga Tellis v. Bombay Municipal Corp., AIR 1986 SC 180; see also DAVID BILCHITZ, POVERTY AND FundAMENTAL Rights: THE JustificATION AND ENFORCEMENT OF SOCIO-ECONOMIC RIGHTS 241 (Oxford, 2007).

64 (1973) 4 S.C.C. 225. 
continuously affirmed the belief that the right to life unquestioningly includes the right to live with 'basic human dignity.' 65 Also, in the case of Kishen Pattnayak $\mathcal{E}$ Anr. $v$. State of Orissa (the first case in India on the Right to Food) the Supreme Court laid down that the right to food is a natural corollary of the right to life and originally emerges from the latter. ${ }^{66}$

In April 2001, the People's Union for Civil Liberties, a nongovernmental organisation filed a writ petition seeking immediate enforcement of the right to food highlighting the irony of thousands of starvation deaths ever year when the government stocks of food grains are throbbing to their capacity. ${ }^{67}$ They argued that the right to remain free from hunger is a fundamental human right recognised under the Constitution of India. Initially the case was brought against the Government of India, the Food Corporation of India (FCI), and six state governments in the context of inadequate draught relief. Later on, the case was extrapolated to include issues of chronic hunger and undernourishment, and the state governments were included as 'respondents'. The petition highlights two aspects of state negligence: failure of the public distribution system and the inadequacy of government draught relief works. The petition requests the government to:

1. To provide immediate open ended employment in draughtaffected villages.

2. To provide 'gratuitous relief' to persons unable to work.

3. To raise food entitlements under the public distribution system.

4. To provide subsidised food grain to all families and the central government to supply free food grain to these programmes. ${ }^{6}$

65 Francis Coralie Mullin v. Administrator Union Territory of Delhi, A.I.R. 1981 S.C. 746.

${ }^{66}$ Kishen Pattnayak \& Anr. v. State of Orissa, A.I.R. 1989 SC 677.

67 People's Union for Civil Liberties v. Union of India, Writ Petition (Civil) 196 of 2001 (Supreme Court of India).

68 HAUGEN, supra note 4. 
The petitioners also sought a direction for the enforcement of a famine code and immediate release of food grains lying in the stocks of the government of India. Directions were also sought requiring the government to frame fresh schemes of public distribution. The court expressed its deep concern that between 2001 and 2003 it passed various directions to ensure that food was provided to the aged, infirm, disabled and destitute men and women who were in danger of starvation and also to pregnant and lactating women and destitute children in cases where they or members of their family did not have sufficient funds to procure food. 69

The Supreme Court of India has taken due cognizance of the everincreasing importance of right to food in the country. The directions issued by the Supreme Court contribute immensely to the realization of the right to food in the country. The Courts' interventions have had three major impacts.

1. "It covered the benefits of the eight nutrition related schemes into legal entitlements (providing $35 \mathrm{~kg}$ of grain per month at highly subsidised prices to 15 million destitute households under the Antyodaya component of the PDS and suchlike);

2. It directed all state governments to provide a cooked midday meal for all children in government assisted schools, and;

3. It directed the state and central governments to adopt specific measures to create public awareness of the programmes and ensure transparency of these schemes/programmes."70

${ }^{69}$ Dr. S. Muralidhar, Upholding the Right to Food, FRONTLINE, Vol. 18, Issue 18 (Sep. 1-14, 2001); see also Dr. S Muralidhar, Economic, Social and Cultural Rights: An Indian Response to the Justiciability Debate in ECONOMIC, SOCIAL AND CUltural RightS IN PRACTICE: THE ROlE OF JUDGES IN IMPLEMENTING ECONOMIC, SOCIAL AND CULTURAL RigHTS (Yash Ghai \& Jill Cottrell ed., 2004).

70 HAUGEN, supra note 4. 
Over the time, the scope of this public interest litigation has considerably expanded. Today it covers a wide range of issues related to the right to food, including the implementation of foodrelated schemes, urban destitution, the right to work, starvation deaths, and even general issues of transparency and accountability. ${ }^{71}$ Also the court has not merely left implementation up to the government. It has appointed commissioners to monitor implementation to ensure that the orders are given effect to. This litigation establishes the possibilities for socio-economic rights to make a major impact on the lives of the most vulnerable in society. ${ }^{72}$

\section{Measures Taken up by the State Government to Provide Adequate Food to its Citizenry}

The current legislative framework for implementation of the human right to food is implicit rather than explicit. There are piecemeal schemes and assistance programmes in India implementing this human right.

Some of the popular ones are:

1. The Public Distribution System (PDS) - this is a system working at the household level to improve food security. It is essentially a food-subsidy program aiming at the poor and is funded by the centre. It ensures the availability of essential commodities like rice, wheat, sugar, edible oils and kerosene to consumers through a network of outlets. It also helps transfer food grains from surplus areas to grain deficit regions. ${ }^{73}$ In 1997, the PDS was targeted. Different ration cards were issued to households "Below the Poverty Line" (BPL) and those "Above the Poverty Line" (APL), and each category has different entitlements. Today, both BPL and

\footnotetext{
71 People's Union for Civil Liberties, Supreme Court Orders On The Right To Food: A Tool For Action: October 2005, http:// www.righttofoodindia.org/ data/scordersprimer.doc (last visited Apr. 1, 2011).

72 BILCHITZ, supra note 63 at 245.

${ }^{73}$ HAUGEN, supra note 4.
} 
APL households are entitled to $35 \mathrm{~kg}$ of grain per month, but the issue price is higher for APL households. ${ }^{74}$

2. Annapurna Yojana - Under this provision old destitutes who cannot derive benefits from the National Old Age Pension Scheme are provided with prescribed amounts of essential food grains. ${ }^{75}$

3. Mid Day Meal Scheme (MDMS) - This scheme is also financially supported by the central government. All children in government or government-aided schools are provided hot cooked mid day meals for at least 200 days a year. ${ }^{76}$

Though these steps are taken up by the Government of India to give adequate recognition to right to food as a fundamental human right in Indian jurisprudence, these measures are piecemeal and require long term vision. "The framework of the right to food is one of the basic economic and social rights that are essential to achieve the 'economic democracy' without which political democracy is, at best, incomplete. The schemes introduced by the government are well designed, yet their implementation has been poor." 77

\section{Measures by Civil Society: The Right to Food Campaign}

Civil societies have also played an important role in promotion of right to food. The right to food campaign began with a writ petition submitted to the Supreme Court in April 2001 by People's Union for Civil Liberties. This petition led to prolonged public interest litigation (P.U.C.L. v. Union of India and Others). ${ }^{78}$ However, it soon became clear that the legal process would not go very far on its

74 People's Union for Civil Liberties, supra note 71.

75 Annapurna Yojana, Monthly Allotment for January, 2006, Food, Supplies $\mathcal{E}$ Consumer Welfare Development, http:/ / fcp.bih.nic.in/Annapurna.htm. (last visited Jun. 20, 2011).

76 HAUGEN, supra note 4.

77 Id.

78 Writ Petition (Civil) 196 of 2001 (Supreme Court of India). 
own. This motivated the effort to build a larger public campaign for the right to food. 79 The right to food campaign is an informal network of organizations and individuals committed to the realization of the right to food in India. It considers that everyone has a fundamental right to be free from hunger and under nutrition. ${ }^{80}$ The campaign states that the primary responsibility for guaranteeing these entitlements rests with the state. Lack of financial resources cannot be accepted as an excuse for abdicating this responsibility. 81

A wide range of activities has been taken up to pursue the campaign. Public hearings, rallies, dharnas, padayatras, actionoriented research and lobbying of Members of Parliament are some of them. On April 9, 2002 the campaign organised a nation-wide day of action on Mid-day Meals. This event was instrumental in persuading several state governments to provide cooked mid-day meals in primary schools. ${ }^{82}$

\section{National Rural Employment Guarantee Act 2005}

One of the long-standing demands of the right to food campaign is the National Rural Employment Guarantee Act, 2005 (NREGA 2005). This demand was partially met in mid-2005 with the enactment of the NREGA 2005. Under this Act, any adult willing to take up casual labour at the minimum wage is entitled to employment on local public works within 15 days, subject to a limit of 100 days per household per year. This Act is indispensible because without right to work there can be no right to food. ${ }^{83}$ The NREGA 2005 is a landmark legislation in the history of social security legislation in India - or indeed, anywhere in the world -

79 People's Union for Civil Liberties, supra note 71.

${ }^{80} \mathrm{Id}$.

${ }^{81} \mathrm{Id}$.

82 People's Union for Civil Liberties, supra note 71.

83 Jean Dreze, Employment Guarantee Act and the Right to Food in FOOD SECURITY AND JUDICIAL ACTIVISM IN INDIA 81-85 (Michael Higgins et al. eds., 2007). 
and promises to be a major tool in the struggle to secure the right to food. The success of NREGA 2005 depends on a great deal of public vigilance on the ground. To this end, a number of groups have organised "social audits", public hearings, padyatras, dharnas and other activities across the country. ${ }^{84}$

\section{Conclusion}

Any serious attempt by the Union Cabinet to address food insecurity in the country must address the overall problem of food production, distribution and absorption. The present Food Security Bill, 2011 is an inadequate attempt which merely deals with the symptoms without targeting the deeper malaise. Its focus is only on distribution, but in doing so retains the much criticised APL/BPL distinction.

It is the realm of food production however, which needs immediate attention, especially since India is in severe agrarian crisis. Growth of food grain production has fallen to $1.7 \%$, below the population growth rate of $1.9 \%$. This translated to a decline in per capita availability of food grains by $3.5 \mathrm{~kg}$ in the period from $1995-2001$. Concurrently, there has been an unprecedented decline in the availability of cereals and pulses in the 15 years from $1991-2004$. Overburdened by loans from local moneylenders and rising input costs, there have been over quarter million farmer suicides in the period 1995 - 2001.85 Unless cultivation becomes viable for the small and marginal farmer, food security is bound to remain a distant dream. Reliance on the international market for domestic consumption is also unsafe because of increasing speculation in food grains, western policies on bio-fuels, and uncertainties in traditional weather patterns due to climate change. In such a world where availability of food in the international market cannot be taken for granted, the link between food security and food

84 People's Union for Civil Liberties, supra note 71.

85 Dr. Suman Sahai, Need for a Different Food Security Law (June 2012), http://www.india-seminar.com/2012/634/634_suman_sahai.htm (last visited Jun. 9, 2012). 
sovereignty becomes crucial. Only those nations which are selfreliant in food production can truly be called food secure.

Tackling the problem of food security in such a comprehensive manner would invariably involve critiquing the predominant model of development. Fundamental shifts in priority, especially on issues such as land use and public investment, would have to be carefully studied and incorporated into the larger policy framework.

The realm of food absorption will require separate attention and includes issues such as provision of clean drinking water and sanitation to rural households. The possibilities of meaningfully linking up scattered government schemes (such as the Rajiv Gandhi National Drinking Water Mission and the Total Sanitation Campaign) to the National Policy of Food Security would also have to be carefully considered.

At present there is no legislative framework to guarantee the right to food. Under international human rights law, governments are committed to take all appropriate measures, including particularly the adoption of legislative measures at national level, for full realization of the rights guaranteed under the Covenant on Economic, Social and Cultural Rights in 1999. Indeed every state has discretion in choosing its own approaches to ensure that everyone is free from hunger. The development of a legislative framework to guarantee adequate food to people will not only assist in defining clearly the different roles that should be played by the different government agencies but will also identify the difficulties that may be encountered in providing adequate food to all. Furthermore, it will also enable individuals to hold institutions accountable and claim their rights when they have been violated. The current climate is centered around an approach which relies on the conferment of this right through a central statute. We urge that since the domestic and international jurisprudence to allow adjudication upon the right is already fertile, the attempts of the state and civil society should be aimed more towards ground realisation of right already present and existing than its concretisation into a statutory right. 